\title{
Effect of age and cyclical heat stress on the serum biochemical profile of broiler chickens
}

\section{Influência da idade e do estresse cíclico de calor no perfil bioquímico sérico em frangos de corte}

\author{
João Paulo Rodrigues Bueno ${ }^{1 *}$; Mara Regina Bueno de Mattos Nascimento²; \\ Julyana Machado da Silva Martins ${ }^{3}$; Cristiane Ferreira Prazeres Marchini4; \\ Luciana Ruggeri Menezes Gotardo ${ }^{5}$; Gabriel Miranda Ribeiro de Sousa ${ }^{6}$; Antonio \\ Vicente Mundim ${ }^{2}$; Ednaldo Carvalho Guimarães ${ }^{7}$; Fabrício Pereira Rinaldi ${ }^{+}$
}

\begin{abstract}
This study aimed to evaluate the influence of age and cyclical heat stress for 1 hour per day on the levels of serum proteins, metabolites, and enzymes in broiler chickens of 21-42 days of age. We used 420 male broiler chickens, Cobb Avian $48^{\mathrm{TM}}$ breed, in a completely randomized experimental design, composed of two treatments and six replicates. The treatments consisted of two thermal environments: one in which broiler chickens were raised under natural conditions of temperature and humidity for the first 42 days of age (control) and another in which chickens were subjected to heat stress at $36^{\circ} \mathrm{C}$, from days 16 to 42, for 1 hour per day (1200-1300 hours). At 21,28,35, and 42 days of age, approximately 5 $\mathrm{mL}$ of blood was collected by cardiac puncture in two birds per replicate. In each serum sample, levels of total protein, albumin, globulin, albumin:globulin ratio, aspartate aminotransferase (AST), alanine aminotransferase (ALT), and gamma-glutamyltransferase (GGT) activity and uric acid, creatinine, total cholesterol, triglycerides, high-density lipoproteins (HDL), very low density lipoproteins (VLDL), low-density lipoproteins (LDL), and glucose levels were determined. Concerning the environment and the age, no significant differences in the levels of glucose, uric acid, ALT, triglycerides, and very low density lipoproteins were observed. There was a significant interaction between the environment and the age for cholesterol and LDL values. At 21 days of age, cholesterol and LDL-cholesterol (LDL-C) were higher in birds under stress than in the control treatment birds, which did not occur in other age groups. Aspartate aminotransferase activity was higher in chickens under cyclical heat stress than in chickens subjected to control treatment and displayed a cubic response regarding the environment. The age of the birds influenced the values of total protein, albumin, globulin, albumin:globulin (A:G) ratio, creatinine, GGT, and HDL. In conclusion, cyclical heat stress, at $36^{\circ} \mathrm{C}$, for one hour, from days 16 to 42 of age increases serum AST, whereas cholesterol and LDL-C levels increase only at day 21, indicating that birds may have adapted to heat stress. Age influenced the activity of AST and GGT and levels of creatinine, total protein, albumin, globulin, A:G ratio, cholesterol, HDL-C, and LDL-C.
\end{abstract}

Key words: Poultry. Cholesterol. Liver enzymes. Glucose.

\footnotetext{
${ }^{1}$ Discente, Curso de Doutorado em Ciências Veterinárias, FAMEV, Universidade Federal de Uberlândia, UFU, Uberlândia, MG, Brasil. E-mail: jprbueno@hotmail.com

2 Profs. Drs., FAMEV, UFU, Uberlândia, MG, Brasil. E-mail: maran@ufu.br; antoniomundim@ufu.br

${ }_{3}^{3}$ Discente, Curso de Doutorado em Zootecnia, EVZ, Universidade Federal de Goiás, UFG, Goiânia, GO, Brasil. E-mail: julyanamachado_zoo@hotmail.com

${ }^{4}$ Prof $^{\mathrm{a}} \mathrm{Dr}^{\mathrm{a}}$, Ciências Biológicas e da Saúde, Universidade de Franca, UNIFRAN, Franca, SP, Brasil. E-mail: cfprazeres@gmail.com

${ }^{5}$ Engenheira de Alimentos, M.e em Ciências Veterinárias, FAMEV, UFU, Uberlândia, MG, Brasil. E-mail: luciana.ruggeri@, hotmail.com

${ }^{6}$ Graduado em Medicina Veterinária, FAMEV, UFU, Uberlândia, MG, Brasil. E-mail: gabrielm.udi@hotmail.com

7 Prof. Dr., FAMAT, UFU, Uberlândia, MG, Brasil. E-mail: ecg@ufu.br

+ In memorian.

*Author for correspondence
} 


\section{Resumo}

Objetivou-se avaliar a influência da idade e do estresse cíclico por calor durante uma hora por dia, nas concentrações das proteínas, metabólitos e enzimas séricas em frangos de corte de 21 a 42 dias de idade. Foram utilizados 420 pintos de corte machos, da linhagem Cobb Avian $48^{\mathrm{TM}}$, em um delineamento inteiramente casualizado, composto de dois tratamentos e seis repetições. Os tratamentos foram constituídos de dois ambientes térmicos: um para frangos de corte criados em condições naturais de temperatura e umidade do primeiro ao $42^{\circ}$ dia de idade (controle); e outro para estressados por calor à 36 ${ }^{\circ} \mathrm{C}$ do $16^{\circ}$ ao $42^{\circ}$ dia, durante uma hora do dia $(12 \mathrm{~h} 00 \mathrm{~m}$ às $13 \mathrm{~h} 00 \mathrm{~m})$. No $21^{\circ}, 28^{\circ}, 35^{\circ}$ e $42^{\circ}$ dias de idade, foram coletados em duas aves por repetição aproximadamente $5 \mathrm{~mL}$ de sangue por punção cardíaca. Foram determinadas em cada amostra de soro as concentrações de proteína total, albumina, globulinas, relação $\mathrm{A} / \mathrm{G}$, aspartato aminotransferase, alanina aminotransferase, gama glutamiltransferase, ácido úrico, creatinina, colesterol total, triacilgliceróis, lipoproteínas de alta densidade, lipoproteínas de muito baixa densidade, lipoproteínas de baixa densidade e glicose. Para as concentrações de glicose, ácido úrico, alanina aminotransferase, triacilgliceróis e lipoproteínas de muito baixa densidade, não houve diferenças significativas para ambiente e idade. Observou-se interação significativa entre ambiente e idade para os valores de colesterol e lipoproteínas de baixa densidade. Aos 21 dias de idade o colesterol e as LDL-C foram maiores nas aves em estresse comparados àquelas do tratamento controle, o que não ocorreu nas demais idades. A aspartato aminotransferase nos frangos sob estresse cíclico de calor foi maior em comparação ao tratamento controle e apresentou efeito cúbico para ambiente. A idade das aves influenciou os valores de proteínas totais, albumina, globulina, albumina: globulina, creatinina, gama glutamiltransferase e das lipoproteínas de alta densidade. Conclui-se que o estresse cíclico de calor por uma hora, a $36^{\circ} \mathrm{C}$, do $16^{\circ}$ ao $42^{\circ}$ dia de idade aumenta aspartato aminotransferase, enquanto colesterol e LDL-C são aumentados somente aos 21 dias, indicando que as aves possam ter se adaptado. A idade influencia os valores de AST, GGT, creatinina, proteínas totais, albumina, globulinas, albumina:globulinas, colesterol, HDL-C e LDL-C.

Palavras-chave: Avicultura. Colesterol. Enzimas hepáticas. Glicose.

\section{Introduction}

The modern broiler chicken is an animal bred for meat production that has been genetically improved to allow for rapid growth and deposition of muscle tissue. These characteristics were obtained due to advances in genetics and applied nutrition. However, the metabolism of these birds is more pronounced, and their thermoregulation ability is ineffective under conditions of high temperature and moisture (BOSCHINI et al., 2011), being highly susceptible to heat stress, with negative effects on the performance (UZUM et al., 2013).

High ambient temperature is considered one of the most important stress factors in poultry production, especially in countries with a tropical climate (KADIM et al., 2008). When birds are subjected to heat stress, they use various strategies such as behavioral, hormonal, physiological, and biochemical adjustments to maintain homeostasis (OGUNTUNJI; ALABI, 2010).
Variations in serum biochemical levels are intrinsically related to climate factors (BARBOSA et al., 2011). In Brazil, there is a paucity of data on the reference levels for hematological values and biochemical parameters in broiler chickens; hence, it is important to establish this profile in broilers in various experimental situations.

Heat stress can be classified as constant or cyclic. Although under natural conditions the ambient temperature is not constant, the majority of the studies on the effects of heat stress on the performance and physiological responses of birds were conducted at high constant temperatures (OLIVEIRA NETO et al., 2000; OLIVEIRA et al., 2006a, 2006b; ROSA et al., 2007).

Yanagi Junior et al. (2001) state that exposure to heat stress for 50 minutes is sufficient for the birds to initiate changes in thermoregulatory responses such as hyperthermia. Therefore, there is a need to study the effects of high temperature in conventional 
sheds on the biochemical parameters of broilers. Moreover, the duration and period of challenge to heat stress have not been much addressed in current studies.

Therefore, the objective of this study was to evaluate the influence of age and cyclical heat stress for 1 hour per day, on serum levels of proteins, metabolites, and enzymes in broiler chickens aged 21-42 days.

\section{Material and Methods}

All procedures in this study were performed in accordance with the Protocol Register CEUA/ UFU 024/10 approved by the Ethics Committee for the Use of Animals at the Federal University of Uberlândia.

The experiment was conducted in the Experimental Farm of Fazenda da Glória, at the Federal University of Uberlândia, Uberlândia, Minas Gerais, Brazil, from March to April 2010. The shed was built in masonry and metal structure, with tile roofing cement, concrete floor, netted walls, double curtains (internal and external), lined with plastic fabric, nebulizers, and ventilators.

In total, 420 1-day old male broiler chickens, Cobb Avian $48^{\mathrm{TM}}$ breed, acquired from a commercial hatchery in the region of Uberlândia, Minas Gerais, Brazil, were used. A completely randomized experimental design was employed, composed of two treatments and six replicates per treatment, with each experimental unit (box) having 35 birds.

The shed was divided into two sections, each measuring $5.60 \mathrm{~m}$ in width, $10.20 \mathrm{~m}$ in length, and $2.80 \mathrm{~m}$ in height, separated by plastic curtains (black and white, double-sided canvas) arranged along the width of the shed. Thus, two thermal environments were equalized: one for broiler chickens raised under natural conditions of temperature and humidity for the first 42 days of age (control) and another for heat stress at $36^{\circ} \mathrm{C}$ from days 16 to 42 for 1 hour per day (1200-1300 hours), through infrared beam hoods installed $1.80 \mathrm{~m}$ above the floor of the shed and $2.40 \mathrm{~m}$ away from the boxes. Each environment comprised six boxes equipped with two drinking fountains, one automatic drinker, and a tubular feeder. The trial period began at age 16 days, when birds kept under natural conditions of temperature and relative humidity (control treatment) displayed a mean body weight of $464.0 \pm 9 \mathrm{~g}$, and the group undergoing cyclical heat stress presented a mean weight of $453.0 \pm 9 \mathrm{~g}$.

During the artificial heating periods (12001300 hours) from day 16 onwards, the ventilators were maintained on to ensure ventilation of the environment. The environment was pre-heated by means of infrared beam hoods for 10 minutes before the beginning of the one-hour challenge period to reach the temperature of heat stress, i.e. above $36^{\circ} \mathrm{C}$. During heat stress, in order to characterize the thermal environment, temperature, and relative humidity were monitored every 10 minutes using a portable Digital Heat Stress Meter, model TGD-200 Instrutherm ${ }^{\circledR}$. At the end of the heat stress period, the curtains were opened to reach the temperature and the humidity of the natural conditions in 10 minutes, and when necessary, fans and nebulizers were applied to obtain conditions of thermal comfort.

For the first 15 days of age (pre-experimental period), all birds were maintained in conditions of temperature and relative humidity, in accordance with the breed manual (GRANJA PLANALTO, 2006). In the hatchery, broilers were vaccinated against Marek and Gumboro disease, and, on day 13 , the attenuated live virus vaccine against Gumboro (Lukert intermediate) was administrated in the water.

All birds received feed and drinking water (3-5 ppm chlorine) ad libitum. The diet was formulated in accordance with the nutritional levels recommended by Rostagno et al. (2005) and produce containing sorghum, soybean meal, degummed soybean oil, dicalcium phosphate, limestone, sodium chloride, 
vitamins, and minerals supplements, and commercial additives. The food program comprised four phases: pre-starter feed (1-7 days), early (8-21 days), fattening (22-33 days), and slaughter (34-42 days).

At ages 21, 28, 35, and 42 days, $\sim 5 \mathrm{~mL}$ of blood was collected from two birds per replicate (12 birds per treatment) by cardiac puncture and divided into two aliquots. One aliquot of $4 \mathrm{~mL}$ was placed in a vacuum tube without anticoagulant for serum biochemistry analysis; the 1-mL aliquot was placed in a tube with EDTA and sodium fluoride for determination of blood glucose levels.

The blood samples were transported in isothermal boxes to the Clinical Laboratory of the Veterinary Hospital of the Federal University of Uberlândia, where they were centrifuged at $720 \times$ $\mathrm{g}$ for five minutes immediately after arrival at the laboratory to separate plasma and serum.

In each serum sample, the following parameters, and respective determination methods, were assessed: concentrations of total proteins, by biuret method; albumin, by Bromocresol Green; globulins, calculated as the difference between total protein and albumin; albumin:globulin ratio; aspartate aminotransferase (AST) and alanine aminotransferase (ALT), by the IFCC-UV kinetic method; gamma glutamyltransferase (GGT), by modified Szasz; uric acid, by Trinder Enzymatic activity; creatinine, by alkaline picrate; total cholesterol and triglycerides by Trinder Enzymatic activity, and high-density lipoproteins-cholesterol (HDL-C), by Trinder Enzymatic activity, after precipitation of low density lipoproteins (LDL-C) and very low density lipoproteins cholesterol (VLDL-C) using reagents liable for magnetic separation. In the fluoridated plasma, the concentrations of glucose were determined by Good Trinder.

The analyses were processed in an automated multichannel Chem Well ${ }^{\circledR}$ analyzer (Awareness Technology, Inc.), using commercial kits (Labtest Diagnóstica ${ }^{\circledR}$, Lagoa Santa, MG). The automatic analyzer was previously calibrated (Calibra $\mathrm{H}$,
Labtest Diagnóstica ${ }^{\circledR}$ ) and checked with control serum (Qualitrol, Labtest Diagnóstica ${ }^{\circledR}$ ). The equation of Friedewald et al. (1972) was used for the calculation of serum concentrations of VLDL-C and LDL-C.

Data were tested for normality (KolmogorovSmirnov test) and homogeneity (Levene's test) using SIRVAR $®$ software. Tukey test at 5\% significance was used to compare the environment, and logistic regression analysis was used to compare age.

\section{Results and Discussion}

There were no significant differences in the concentrations of glucose, uric acid, ALT, triglycerides, and VLDL-C between the two environments and among different ages (Table 1). According to González and Silva (2006), serum glucose concentration may increase with chronic stress. However, in the cyclical stress situation of this experiment there were no changes. This finding corroborates those obtained by Laganá et al. (2007), who found no differences in glucose in broiler chickens subjected to cyclical heat stress. According to Puvadolpirod and Thaxton (2000), who found higher values of glucose in chickens injected with the hormone $\mathrm{ACTH}$, hyperglycemia is related with acute stress episodes, in which the stress factor acts suddenly. The responses observed in this experiment indicate a possible acclimatization of birds under cyclical heat stress.

There was a significant interaction between environment and age for the values of cholesterol and LDL. At age 21 days, cholesterol and LDL-C levels were higher in birds under stress than in birds subjected to the control treatment (Table 2). This did not occur in other age groups, suggesting the birds have adapted to the heat. The body reacts to a stress agent in an attempt to maintain homeostasis; thus, stress is a consequence and not the cause and has adaptive value (MACHADO FILHO; HÖRTZEL, 2000). This is the demonstration that animals develop response mechanisms when their homeostasis is 
under threat, requiring physiological or behavioral adjustments to suit the adverse aspects of handling or environment. Homeostasis represents a relative constancy of the physicochemical properties of the internal environment of an organism, which are maintained by regulatory mechanisms (IUPS THERMAL COMISSION, 2001).

Table 1. Mean values of the biochemical parameters analyzed in broiler chickens under cyclical heat stress from 21 to 42 days of age.

\begin{tabular}{|c|c|c|c|c|c|c|c|c|c|}
\hline \multirow{2}{*}{ Parameters } & \multicolumn{2}{|c|}{ Environment } & \multicolumn{3}{|c|}{ Age } & \multicolumn{4}{|c|}{ P-Value } \\
\hline & Control & Stress & 21 & 28 & 35 & 42 & $\mathrm{E}$ & $\mathrm{A}$ & $\mathrm{E} \times \mathrm{A}$ \\
\hline Glucose $\left(\mathrm{mg} \mathrm{dL} \mathrm{L}^{-1}\right)$ & 274.1 & 255.4 & 258.5 & 269.4 & 282.7 & 248.4 & $\mathrm{~ns}$ & ns & ns \\
\hline $\operatorname{AST}\left(\mathrm{U} \mathrm{L}^{-1}\right)$ & 190.9 & 218.6 & 227.2 & 240.3 & 69 & 282.5 & $0.0375^{2}$ & $0.0000^{3}$ & ns \\
\hline $\operatorname{ALT}\left(\mathrm{U} \mathrm{L}^{-1}\right)$ & 21.6 & 18.6 & 20.9 & 21.3 & 17.1 & 21.2 & ns & ns & ns \\
\hline $\operatorname{GGT}\left(\mathrm{U} \mathrm{L}^{-1}\right)$ & 11.4 & 12.7 & 10.5 & 15.1 & 10.2 & 12.4 & ns & $0.0138^{3}$ & ns \\
\hline Proteins $\left(\mathrm{g} \mathrm{L}^{-1}\right)$ & 2.75 & 2.92 & 2.92 & 3.13 & 2.63 & 2.67 & ns & $0.0006^{3}$ & ns \\
\hline Albumin $\left(\mathrm{g} \mathrm{L}^{-1}\right)$ & 1.52 & 1.52 & 1.55 & 1.62 & 1.28 & 1.61 & ns & $0.0002^{3}$ & ns \\
\hline Globulin ( $\left.\mathrm{g} \mathrm{L}^{-1}\right)$ & 1.23 & 1.40 & 1.36 & 1.50 & 1.35 & 1.05 & ns & $0.0061^{3}$ & ns \\
\hline Albumin:Globulin $\left(\mathrm{g} \mathrm{L}^{-1}\right)$ & 1.34 & 1.19 & 1.19 & 1.14 & 1.00 & 1.75 & ns & $0.0089^{3}$ & ns \\
\hline Uric acid $\left(\mathrm{mg} \mathrm{dL}^{-1}\right)$ & 2.47 & 3.16 & 3.03 & 2.37 & 3.08 & 2.78 & ns & ns & ns \\
\hline Creatinine (mg dL $\left.{ }^{-1}\right)$ & 0.71 & 0.63 & 0.47 & 0.53 & 1.24 & 0.44 & ns & $0.0000^{3}$ & ns \\
\hline Cholesterol (mg dL $\left.{ }^{-1}\right)$ & 119.2 & 136.9 & 127.3 & 154.8 & 127.2 & 102.9 & 0.0032 & 0.0000 & $0.0423^{1}$ \\
\hline $\mathrm{LDL}\left(\mathrm{mg} \mathrm{dL}^{-1}\right)$ & 79.7 & 95.5 & 78.4 & 109.3 & 92.1 & 70.7 & 0.0032 & 0.0000 & $0.0490^{1}$ \\
\hline HDL (mg dL $\left.{ }^{-1}\right)$ & 32.9 & 34.6 & 40.7 & 39.5 & 28.8 & 26.0 & ns & $0.0000^{3}$ & ns \\
\hline $\operatorname{VLDL}\left(\mathrm{mg} \mathrm{dL}^{-1}\right)$ & 6.52 & 6.75 & 8.13 & 6.00 & 6.26 & 6.14 & ns & ns & ns \\
\hline Triacylglycerols $\left(\mathrm{mg} \mathrm{dL}^{-1}\right)$ & 32.6 & 33.7 & 40.6 & 30.0 & 31.4 & 30.7 & ns & ns & ns \\
\hline
\end{tabular}

E: Environment; A: Age; ${ }^{1}$ Significant for the environment $\mathrm{x}$ age interaction (Table 2 and Figures 1 and 2); ${ }^{2}$ Significant only for environment; Tukey test at $5 \%$ (Table 3); ${ }^{3}$ Significant only for age; Regression (Figures 3 to 10 ).

Table 2. Cholesterol and LDL-C values of broiler chickens in the different thermal environments, within each age group.

\begin{tabular}{lcccc}
\hline & \multicolumn{3}{c}{ Age (Days) } \\
\hline Cholesterol $\left(\mathrm{mg} \mathrm{dL}^{-1}\right)$ & 21 & 28 & 35 & 42 \\
Control & & & & \\
Stress & $104.48 \mathrm{~b}$ & $146.26 \mathrm{a}$ & $125.33 \mathrm{a}$ & $100.71 \mathrm{a}$ \\
LDL-C $\left(\mathrm{mg} \mathrm{dL}^{-1}\right)$ & $150.15 \mathrm{a}$ & $163.36 \mathrm{a}$ & $129.16 \mathrm{a}$ & $105.11 \mathrm{a}$ \\
Control & & & & \\
Stress & $58.66 \mathrm{~b}$ & $100.66 \mathrm{a}$ & $91.08 \mathrm{a}$ & $68.38 \mathrm{a}$ \\
\hline
\end{tabular}

For each parameter, values followed by lowercase letters in the same column differ by Tukey test at $5 \%$ significance.

It is known that stress can cause an increase in total cholesterol levels by increasing LDL and decreasing HDL, favoring cardiovascular diseases (BORSA et al., 2011). However, the plasma concentrations of cholesterol for most bird species vary between 100 and $250 \mathrm{mg} \mathrm{dL}^{-1}$ (LUMEIJ, 1997); in this study, cholesterol levels remained within the physiological limits for the species regardless of the environment and age.

The serum concentrations of cholesterol of broiler chickens in the control treatment displayed a quadratic response, with estimated increase from 
21 to 31 days and decreasing until 42 days. The quadratic effect was also observed in the animals subjected to stress but with an estimated increase from 21 to 25 days and decreasing until slaughter (Figure 1). This behavior is different from that reported by González et al. (2001), who observed an increase of cholesterol at 47 days compared to 21 and 32 days, and from that reported by Silva et al. (2007), who observed higher values of cholesterol

Figure 1. Behavior of cholesterol in broiler chickens with increasing age within each environment (comfort and stress).

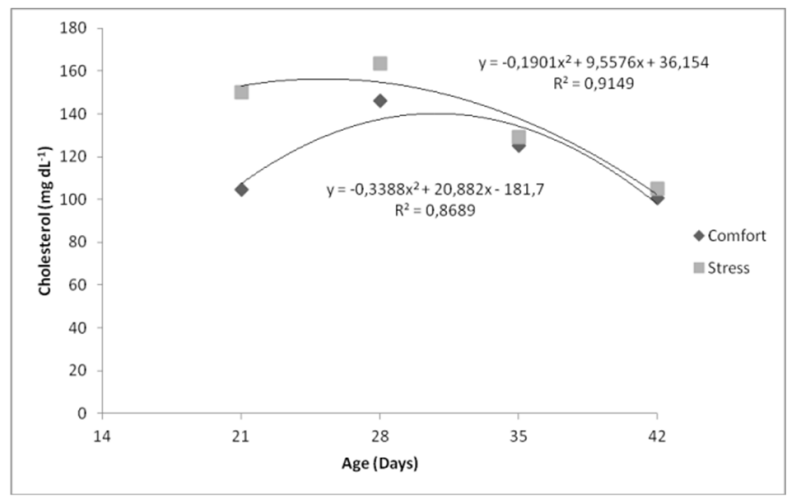

Aspartate aminotransferase activity in chickens under cyclical heat stress was higher than in those subjected to the control treatment, regardless of age (Table 3). However, only AST values higher than up to 21 days, with a decrease at 35 days and an increase at 42 days.

In the birds in thermal comfort (control treatment), the LDL-C displayed a quadratic response, with an estimated increase from 21 to 32 days, decreasing until 42 days. In birds under stress, the effect was also quadratic, with an estimated increase from 21 to 28 days, decreasing until 42 days (Figure 2).

Figure 2. Behavior of LDL-C levels in broiler chickens with increasing age within each environment (comfort and stress).

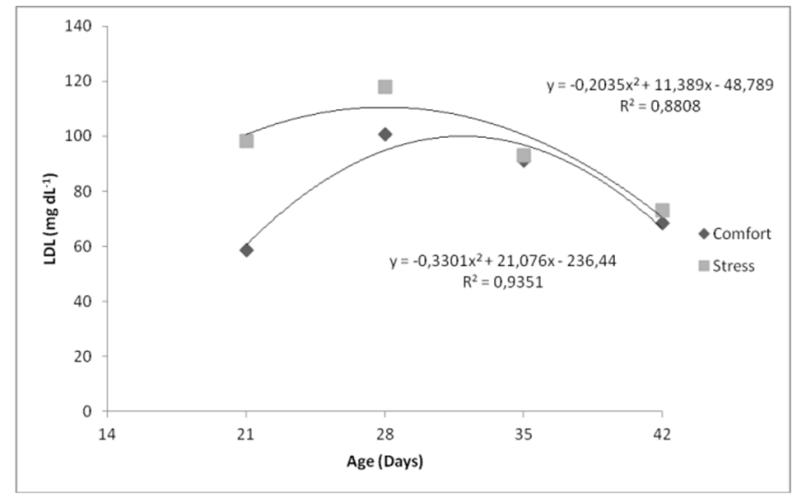

$275 \mathrm{U} \mathrm{L}^{-1}$ suggest an increase in activity, which may be related to hepatic or muscular disorders, and values above $800 \mathrm{U} \mathrm{L}^{-1}$ are highly suggestive of severe liver damage (CAMPBELL, 2004; CAPITELLI; CROSTA, 2013).

Table 3. Value of aspartate aminotransferase (AST) in broiler chickens in different environments.

\begin{tabular}{ccc}
\hline \multirow{2}{*}{ Parameter } & \multicolumn{2}{c}{ Environment } \\
\cline { 2 - 3 } & Thermal comfort & Cyclic heat stress \\
\hline AST $\left(\mathrm{U} \mathrm{L}^{-1}\right)$ & $190.95 \mathrm{~b}$ & $218.62 \mathrm{a}$ \\
\hline
\end{tabular}

Values followed by different lowercase letters in the row differ by Tukey test at $5 \%$ significance.

Aspartate aminotransferase activity presented a cubic response, with an estimated increase from 21 to 24 days of age and a reduction up to 36 days, increasing again up to 42 days regardless of the environment (Figure 3). These results differ from those of Silva et al. (2007), who observed a progressive increase in AST with age in broiler chickens, and those of Borsa et al. (2006), who observed no effect of age on the variation of this enzyme.

The high activity of AST in the liver, skeletal muscle, heart, brain, and kidneys, unlike that of ALT that is specific to the liver, may explain the variation 
of this enzyme with the age of the birds (LUMEIJ, 1997; CAMPBELL, 2004).

The age of the birds influenced the values of total protein, albumin, globulin, albumin:globulin ratio, creatinine, GGT, and HDL-C; however, the thermal environment did not influence these values.

Total protein levels presented a cubic response with estimated increase from 21 to 25 days, decreasing until 39 days, and rising again up to 42

Figure 3. Behavior of AST in broiler chickens with increasing age.

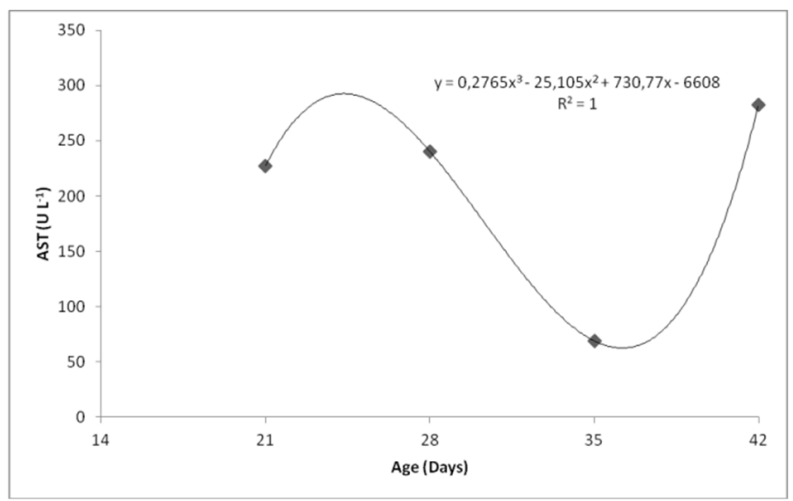

Figure 5. Behavior of albumin in broiler chickens with increasing age.

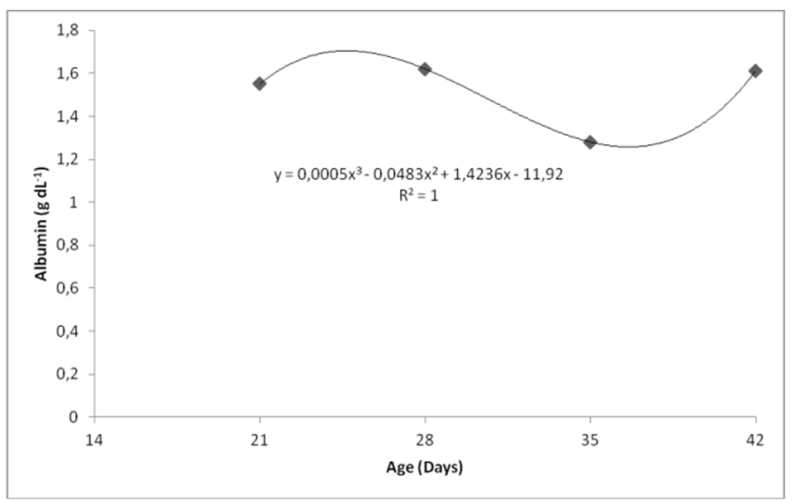

Total proteins are significant as their imbalance is indicative of acute or chronic inflammatory conditions. Owing to an increase in globulins and a decrease in albumin, the decrease in the A:G ratio is indicative of inflammation, peritonitis, aspergillosis, days of age (Figure 4). Albumin levels showed a cubic response with estimated increase from 21 to 23 days, decreasing until 40 days, and increasing again up to 42 days (Figure 5).

Globulin levels showed a quadratic response with an estimated increase from 21 to 28 days, decreasing until 42 days (Figure 6), while A:G ratio displayed a quadratic response, though with an estimated decrease from 21 to 28 days and increasing until 42 days (Figure 7).

Figure 4. Behavior of total proteins of broiler chickens with increasing age.

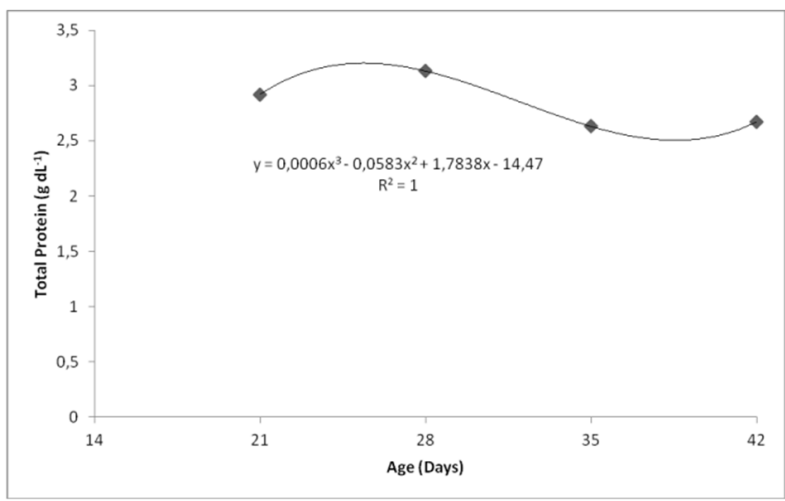

Figure 6. Behavior of globulin in broiler chickens with increasing age.

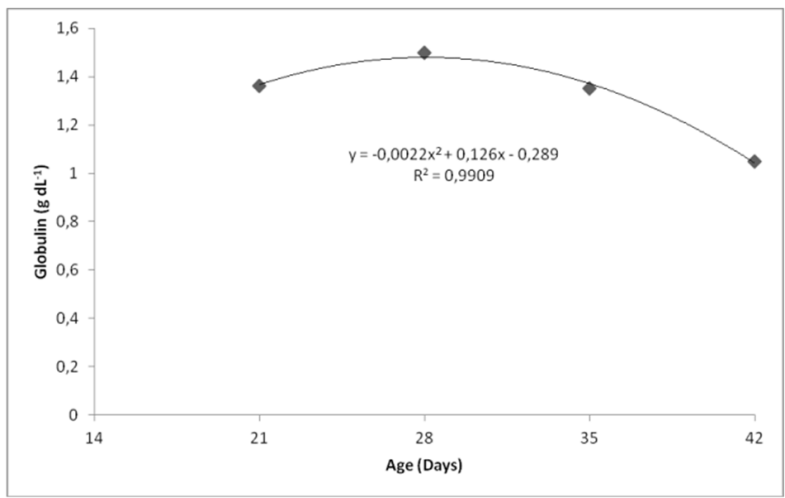

psittacosis, tuberculosis, nephropathies, and liver failure (LUMEIJ, 1997; JONES, 1999).

Conversely, González et al. (2001) found an increase in total protein and globulin levels with age, though albumin did not change. Total protein values 
were as follows: $25 \mathrm{~g} \mathrm{~L}^{-1}$ at 21 days, $29.7 \mathrm{~g} \mathrm{~L}^{-1}$ at 32 days, and $35.9 \mathrm{~g} \mathrm{~L}^{-1}$ at 47 days. Globulin levels were as follows: $8.5 \mathrm{~g} \mathrm{~L}^{-1}$ at 21 days, $14.6 \mathrm{~g} \mathrm{~L}^{-1}$ at 32 days, and $19.6 \mathrm{~g} \mathrm{~L}^{-1}$ at 47 days. Albumin levels were as follows: $16.5 \mathrm{~g} \mathrm{~L}^{-1}$ at 21 days, $15.1 \mathrm{~g} \mathrm{~L}^{-1}$ at 32 days, and $16.3 \mathrm{~g} \mathrm{~L}^{-1}$ at 47 days. Silva et al. (2007) found no influence of age on the values of albumin, while total protein levels increased in the last week.

Figure 7. Behavior of the albumin:globulin ratio in broiler chickens with increasing age.

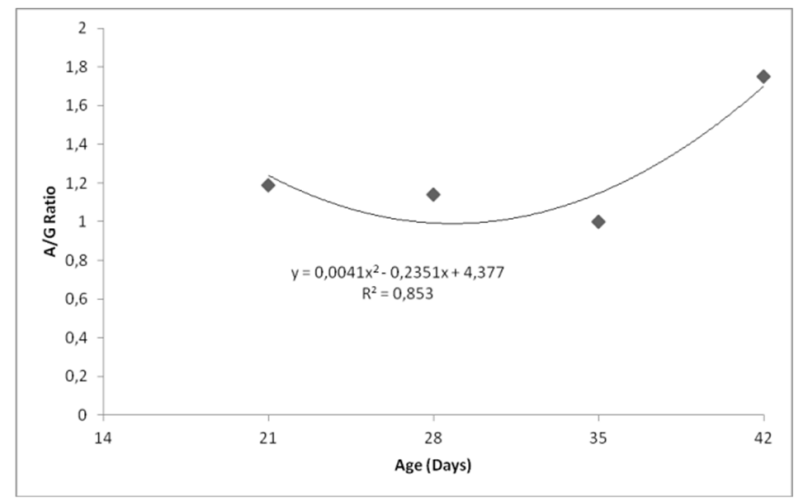

Gamma-glutamyltransferase presented a cubic response with an estimated increase from 21 to 26 days, decreasing until 37 days and increasing again up to 42 days (Figure 9). According to Radin (2003), GGT is found in the liver, pancreas, kidney, and intestine. However, increases in the serum concentrations are usually caused by increased hepatic production because, according to González and Silva (2006), GGT of only hepatic origin is usually found in plasma, since GGT from the kidney is excreted in the urine. The authors also stress that the role of GGT is not very well understood; however, it is believed to be related
Creatinine showed a cubic response with an estimated decrease at 21 and 22 days, increasing up to 40 days and decreasing up to 42 days (Figure 8). The behavior of serum creatinine in this study was similar to that reported by Silva et al. (2007), with values of $0.49 \mathrm{mg} \mathrm{dL}^{-1}$ at 21 days, $0.59 \mathrm{mg} \mathrm{dL}^{-1}$ at 35 days, and $0.46 \mathrm{mg} \mathrm{dL}^{-1}$ at 42 days.

Figure 8. Behavior of creatinine in broiler chickens with increasing age.

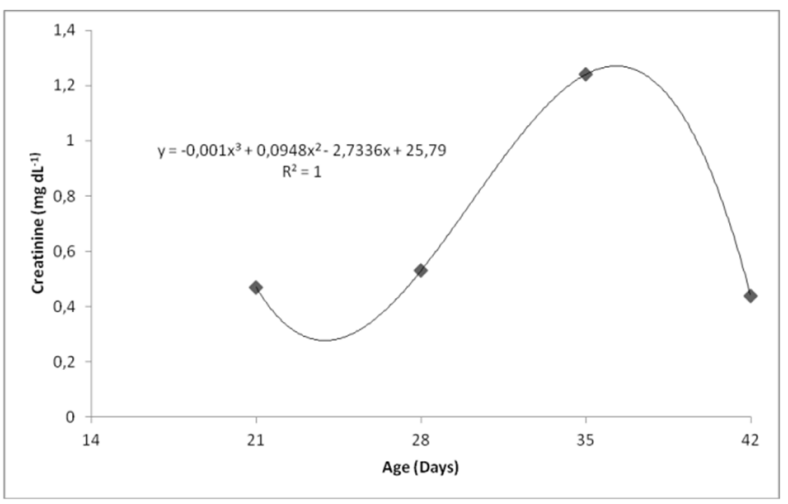

with the metabolism of glutathione and can indicate cholestasis and proliferation of bile ducts in the liver of birds. Gamma-glutamyltransferase displayed different activity from that reported by Silva et al. (2007), where values of $26.86 \mathrm{U} \mathrm{L}^{-1}$ at 21 days, $37.32 \mathrm{U} \mathrm{L}^{-1}$ at 35 days, and $21.28 \mathrm{U} \mathrm{L}^{-1}$ at 42 days were registered. In this study, the behavior of GGT also differed from that observed by Borsa et al. (2006), who found no changes with increasing age.

High-density lipoproteins cholesterol, in turn, displayed a cubic response, with an estimated increase from 21 to 23 days, decreasing up to 40 days and increasing again up to 42 days (Figure 10). 
Figure 9. Behavior of gamma-glutamyltransferase (GGT) in broiler chickens with increasing age.

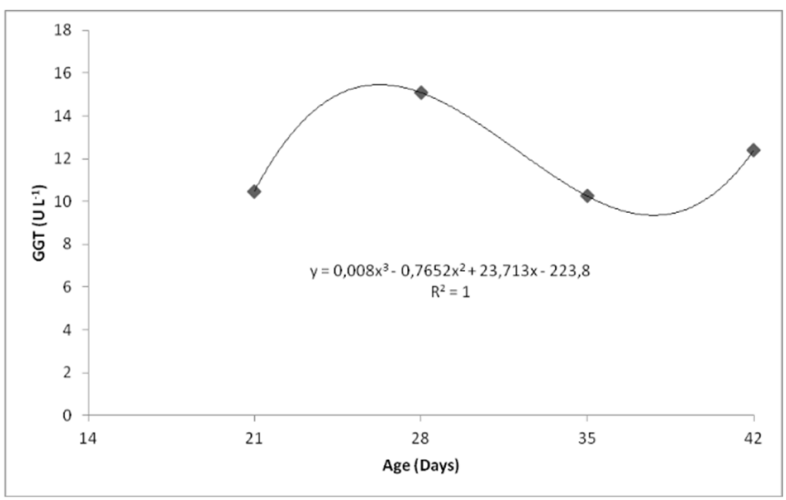

\section{Conclusions}

Cyclic heat stress, at $36^{\circ} \mathrm{C}$ for one hour, from the $16^{\text {th }}$ to the $42^{\text {nd }}$ day of age of broiler chickens does not alter ALT, GGT, uric acid, creatinine, total protein, albumin, globulin, A:G ratio, glucose, HDL-C, VLDL-C, and triglycerides; however, it increases AST. Cholesterol and LDL-C levels are increased only at 21 days, indicating that birds may have adapted to heat stress.

Age does not influence the values of glucose, uric acid, ALT, triglycerides, and VLDL-C; however, it influences the values of AST, GGT, creatinine, total protein, albumin, globulin, A:G ratio, cholesterol, HDL-C, and LDL-C.

\section{Referências}

BARBOSA, T. S.; MORI, C. K.; POLÔNIO, L. B.; PONSANO, E. H. G.; CIARLINI, P. C. Perfil bioquímico sérico de galinhas poedeiras na região de Araçatuba, SP. Semina: Ciências Agrárias, Londrina, v. 32, n. 4, p. 1583-1588, 2011.

BORSA, A.; KOHAYAGAWA, A.; BORETTI, L. P.; SAITO, M. E. Efeitos da interação entre aflatoxicoses e doença infecciosa bursal sobre níveis de enzimas de função hepática, colesterol e triglicerídeos em frangos de corte. Veterinária em Foco, Canoas, v. 8, n. 2, p. 132142, 2011.

BORSA, A.; KOHAYAMA, A.; BORETTI, L. P.; SAITO, M. E.; KUIBIDA, K. Níveis séricos de enzimas de
Figure 10. Behavior of HDL-C in broiler chickens with increasing age.

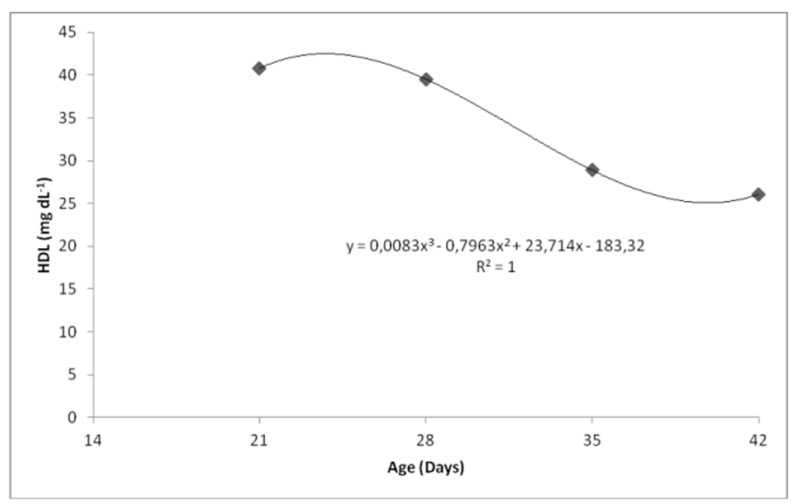

função hepática em frangos de corte de criação industrial clinicamente saudáveis. Arquivo Brasileiro de Medicina Veterinária e Zootecnia, Belo Horizonte, v. 58, n. 4, p. 675-677, 2006.

BOSCHINI, C.; GONÇALVES, F. M.; CATALAN, A. A. S.; BAVARESCO, C.; GENTILINI, F. P.; ANCIUTI, M. A.; DIONELLO, N. J. L. Relação entre a proteína de choque térmico e o estresse térmico em frangos de corte. Archivos de Zootecnia, Córdoba, v. 60, n. 1, p. 63-77, 2011.

CAMPBELL, T. W. Clinical chemistry of birds. In: THRALL, M. A.; BAKER, D. C.; CAMPBELL, T. W.; DeNICOLA, D.; FETTMAN, M. J.; LASSEN, E. D.; REBAR, A.; WEISER, G. Veterinary hematology and clinical chemistry. Philadelphia: Lippincott Williams \& Wilkins, 2004. p. 479-492.

CAPITELLI, R.; CROSTA, L. Overview of psittacine blood analysis and comparative retrospective study of clinical diagnosis, hematology and blood chemistry in selected psittacine species. Veterinary Clinics of North America: Exotic Animal Practice, Texas, v. 16, n. 1, p. 71-120, 2013.

FRIEDEWALD, W. T.; LEVY, R. I.; FREDRICSON, D. S. Estimation of the concentration of low-density lipoprotein cholesterol in plasma without use of the preparative ultracentrifuge. Clinical Chemistry, Baltimore, v. 18, n. 6, p. 499-502, 1972.

GONZÁLEZ, F. H. D.; HAIDA, K. S.; MAHL, D.; GIANNESI, G.; KRONBAUER, E. Incidência de doenças metabólicas em frangos de corte no Sul do Brasil e uso do perfil bioquímico sanguíneo para o seu estudo. Revista Brasileira de Ciência Avícola, Campinas, v. 3, n. 2, p. 141-147, 2001. 
GONZÁLEZ, F. H. D.; SILVA, S. C. Introdução à bioquímica clínica veterinária. 2. ed. Porto Alegre: Universidade Federal do Rio Grande do Sul, 2006. 364 p.

GRANJA PLANALTO. Manual do frango de corte. Guapiaçu: Cobb-Vantress Brasil, 2006. 70 p. Modelo revisão 03. Disponível em: $<$ http://www.granjaplanalto. com.br/MANUAL_MOD\%20REV.\%2003_18_09_06. pdf $>$. Acesso em: 5 mar. 2010.

INTERNATIONAL UNION OF PHYSIOLOGICAL SCIENCES - IUPS Thermal comission. Glossary of terms for thermal physiology. $3^{\text {th }}$ ed. The Japanese Journal of Physioloty, Tokyo, v. 51, n. 2, p. 245-280, 2001.

JONES, M. P. Avian clinical pathology. Veterinary Clinics of North America Exotic Animal Practice, Maryland Heights, v. 2, n. 3, p. 663-687, 1999.

KADIM, I. T.; AL-QAMSHUI, B. H. A.; MAHGOUB, O.; AL-MARZOOQ, W.; JOHNSON, E. H. Effect of seasonal temperatures and ascorbic acid supplementation on performance of broiler chickens maintained in closed and open-sided houses. International Journal of Poultry Science, Faisalabad, v. 7, n. 7, p. 655-660, 2008.

LAGANÁ, C.; RIBEIRO, A. M. L.; GONZÁLEZ, F. H. D.; LACERDA, L. A.; KRATZ, L. R.; BARBOSA, P. R. Níveis dietéticos de proteína e gordura e parâmetros bioquímicos, hematológicos e empenamento em frangos de corte estressados pelo calor. Revista Brasileira de Zootecnia, Viçosa, MG, v. 36, n. 6, p. 1783-1790, 2007.

LUMEIJ, J. T. Avian clinical biochemistry. In: KANEKO, J. J.; HARVEY, J. W.; BRUSS, M. L. Clinical biochemistry of domestic animals. San Diego: Academic Press, 1997. p. 857-883.

MACHADO FILHO, L. C. P.; HÖTZEL, M. J. Bem estar dos suínos. In: SEMINÁRIO INTERNACIONAL DE SUINOCULTURA, 5., 2000, São Paulo. Anais... São Paulo: Gessulli, 2000. p. 70-82.

OGUNTUNJI, A. O.; ALABI, O. M. Influence of high environmental temperature on egg production and shell quality: a review. World's Poultry Science Journal, London, v. 66, n. 6, p. 739-749, 2010.

OLIVEIRA, G. A.; OLIVEIRA, R. F. M.; DONZELE, J. L.; CECON, P. R.; VAZ, R. G. M. V.; ORLANDO, U. A. D. Efeito da temperatura ambiente sobre o desempenho e as características de carcaça de frangos de corte dos 22 aos 42 dias. Revista Brasileira de Zootecnia, Viçosa, MG, v. 35, n. 4, p. 1398-1405, 2006a.
OLIVEIRA, R. F. M.; DONZELE, J. L.; ABREU, M. L. T.; FERREIRA, R. A.; VAZ, R. G. M. V.; CELLA, P. S. Efeitos da temperatura e da umidade relativa sobre o desempenho e o rendimento de cortes nobres de frangos de corte de 1 a 49 dias de idade. Revista Brasileira de Zootecnia, Viçosa, MG, v. 35, n. 3, p. 797-803, 2006 b.

OLIVEIRA NETO, A. R.; OLIVEIRA, R. F. M.; DONZELE, J. L.; ROSTAGNO, H. S.; FERREIRA, R. A.; MAXIMIANO, H. C.; GASPARINO, E. Efeito da temperatura ambiente sobre o desempenho e características de carcaça de frangos de corte alimentados com dieta controlada e dois níveis de energia metabolizável. Revista Brasileira de Zootecnia, Viçosa, MG, v. 29, n. 1, p. 183-190, 2000.

PUVADOLPIROD, S.; THAXTON, J. P. Model of physiological stress in chickens 1 . Response parameters. Poultry Science, Champaign, v. 79, n. 4, p. 363-369, 2000.

RADIN, M. J. Interpretação de perfis bioquímicos. In: FENNER, W. R. Consulta rápida em clínica veterinária. Rio de Janeiro: Editora Guanabara, 2003. p. 120-128.

ROSA, P. S.; FARIA FILHO, D. E.; DAHLKE, F.; VIEIRA, B. S.; MACARI, M.; FURLAN, R. L. Performance and carcass characteristics of broiler chickens with diferente growth potential and submitted to heat stress. Revista Brasileira de Ciência Avícola, Campinas, v. 9, n. 3, p. 181-186, 2007.

ROSTAGNO, H. S.; ALBINO, L. F. T.; DONZELE, J. L.; GOMES, P. C.; OLIVEIRA, R. F.; LOPES, D. C.; FERREIRA, A. S.; BARRETO, S. L. T. Tabelas brasileiras para aves e suínos: composição de alimentos e exigências nutricionais. Viçosa, MG: Universidade Federal de Viçosa, 2005. 186 p.

SILVA, P. R. L.; FREITAS NETO, O. C.; LAURENTIZ, A. C.; JUNQUEIRA, O. M.; FAGLIARI, J. J. Blood serum components and serum protein test of hybro-PG broilers of different ages. Revista Brasileira de Ciência Avícola, Campinas, v. 9, n. 4, p. 229-232, 2007.

UZUM, M. H.; ORAL TOPLU, H. D. Effects of stocking density and feed restriction on performance, carcass, meat quality characteristics and some stress parameters in broilers under heat stress. Revue de Médecine Vétérinaire, Toulouse, v. 164, n. 12, p. 546-554, 2013.

YANAGI JUNIOR, T.; XIN, H.; GATES, R. S. Modeling partial surface evaporative cooling of chickens. In: ASAE ANNUAL INTERNATIONAL, 2001. St Joseph. Meeting... Sacramento, St Joseph: ASAE, 2001. p. 1-16. 